
DICTIONARY

April 1995 
This report has been reproduced from the best available copy. Available in paper copy and microfiche.

Number of pages in this report: 46

DOE and DOE contractors can obtain copies of this report from:

Office of Scientific and Technical Information

P.0. Box 62

Oak Ridge, TN 37831

(615) 576-8401

This report is publicly available from:

National Technical Information Service

Department of Commerce

5285 Port Royal Road

Springfield, VA 22161

(703) 487-4650 


\section{DISCLAIMER}

Portions of this document may be illegible in electronic image products. Images are produced from the best available original document. 


\title{
GROUND WATER \\ WORK BREAKDOWN STRUCTURE \\ DICTIONARY
}

April 1995

\author{
Prepared for \\ U.S. Department of Energy \\ UMTRA Project \\ Albuquerque, New Mexico \\ Prepared by \\ Jacobs Engineering Group Inc. \\ Albuquerque, New Mexico
}

\section{DISCLAIMER}

This report was prepared as an account of work sponsored by an agency of the United States Government. Neither the United States Government nor any agency thereof, nor any of their employees, makes any warranty, express or implied, or assumes any legal liability or responsibility for the accuracy, completeness, or usefulness of any information, apparatus, product, or process disclosed, or represents that its use would not infringe privately owned rights. Reference herein to any specific commercial product, process, or service by trade name, trademark, manufacturer, or otherwise does not necessarily constitute or imply its endorsement, recommendation, or favoring by the United States Government or any agency thereof. The views and opinions of authors expressed herein do not necessarily state or reflect those of the United States Government or any agency thereof. 


\section{TABLE OF CONTENTS}

Section

Page

SITE CHARACTERIZATION (05) $\ldots \ldots \ldots \ldots \ldots \ldots \ldots \ldots \ldots \ldots \ldots \ldots \ldots$

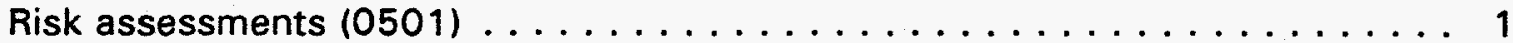

Site observational work plans (0502) . . . . . . . . . . . . . . . 2

Characterization systems installation $(0503) \ldots \ldots \ldots \ldots \ldots \ldots$

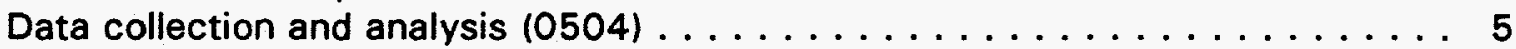

REMEDIAL ACTION COMPLIANCE AND DESIGN DOCUMENTATION $(10) \ldots \ldots \ldots$

Draft remedial action plans $(1001) \ldots \ldots \ldots \ldots \ldots \ldots \ldots \ldots \ldots$

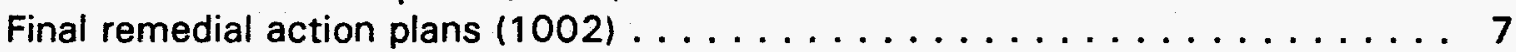

Bid package process (1003) . . . . . . . . . . . . . . . . 8

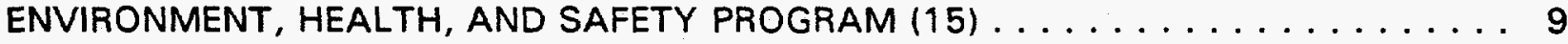

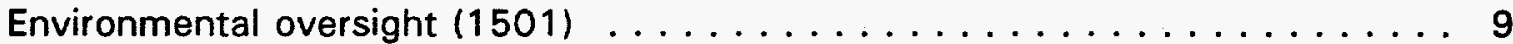

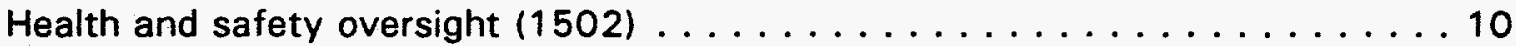

Programmatic environmental impact statement (1503) . . . . . . . . . 12

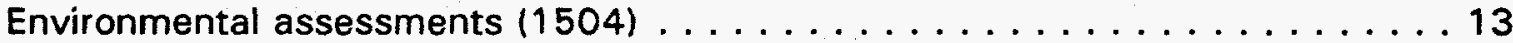

TECHNOLOGY ASSESSMENT $(20) \ldots \ldots \ldots \ldots \ldots \ldots \ldots \ldots \ldots \ldots$

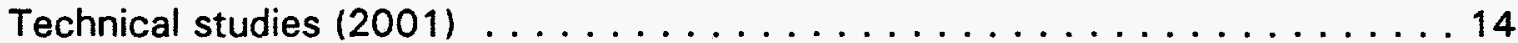

Technology transfer $(2002) \ldots \ldots \ldots \ldots \ldots \ldots \ldots \ldots$

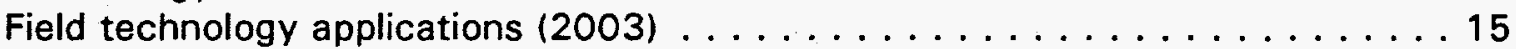

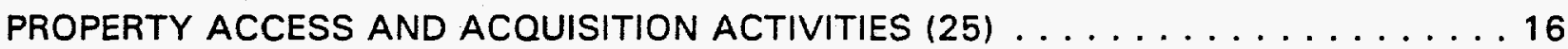

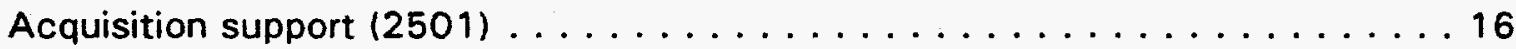

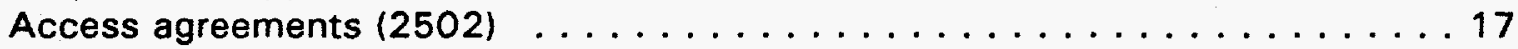

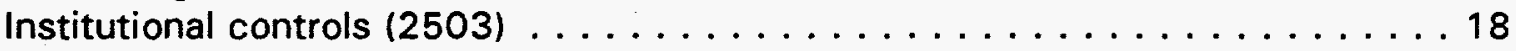

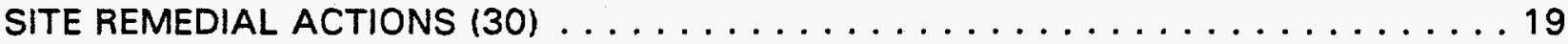

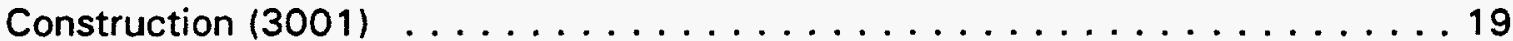

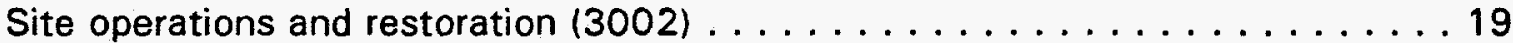

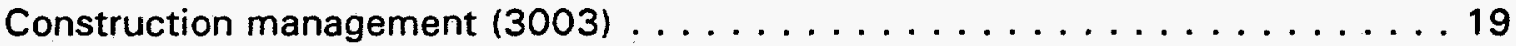

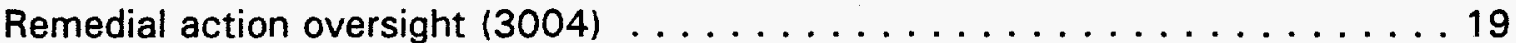

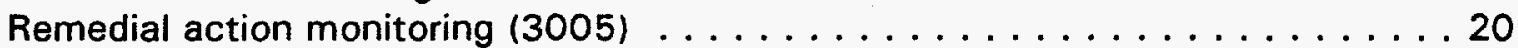

LONG TERM SURVEILLANCE AND LICENSING (35) $\ldots \ldots \ldots \ldots \ldots \ldots \ldots \ldots$

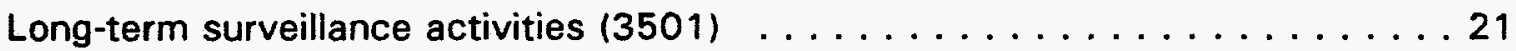

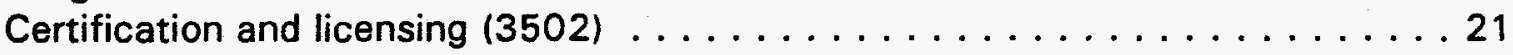

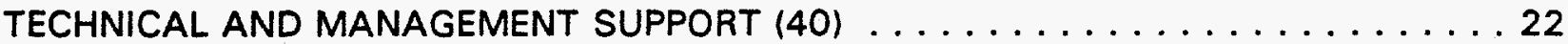

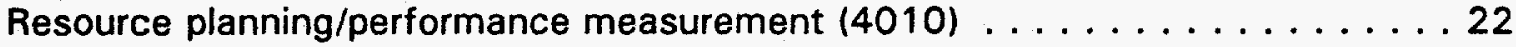

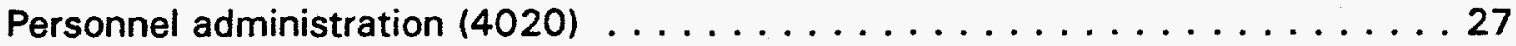

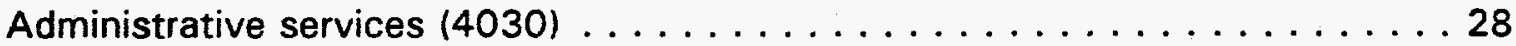

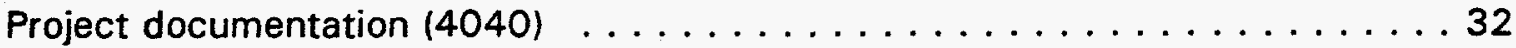

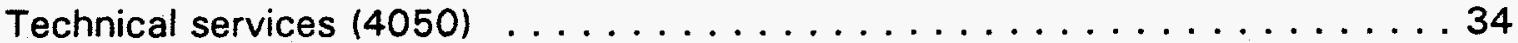




\section{TABLE OF CONTENTS (Concluded)}

$\underline{\text { Section }}$

Page

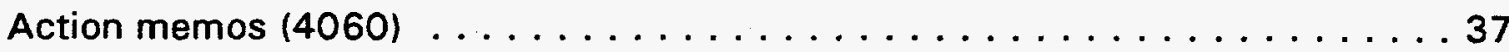

LIST OF CONTRIBUTORS $\ldots \ldots \ldots \ldots \ldots \ldots \ldots \ldots \ldots \ldots \ldots \ldots \ldots$

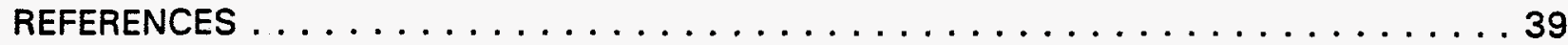




\section{LIST OF ACRONYMS}

Acronym

APM

ATLAS

BCWS

BLM

BLRA

CCB

COR

CPM

CX

DOE

DOE-HQ

EA

EH\&S

GPO

ICE

IPMS

ISPS

ITR

JEG

LAN

LTSP

MOU

MPCE

NEPA

NOI

NRC

OBS

ODC

ORPS

OSHA

PEIS

PMCS

PTS

OA

OC

RAC

RAP

SAP

SAR

SOP

SOWP

SPEAR

TAC

TAILS

\section{Definition}

assistant project manager

Automated Logging and Awareness System

budgeted cost for work scheduled

Bureau of Land Management

baseline risk assessment

change control board

contracting officer representative

critical path methodology

categorical exclusions

U.S. Department of Energy

DOE Headquarters

environmental assessment

Environmental Health and Safety

Government Printing Office

independent cost estimate

Integrated Project Management System

Information Systems Planning and Support

independent technical review

Jacobs Engineering Group Inc.

local area network

long-term surveillance plan

memorandum of understanding

major project cost estimate

National Environmental Policy Act

notice of intent

U.S. Nuclear Regulatory Commission

organizational breakdown structure

other direct costs

Occurrence Reporting and Processing System

Occupational Safety and Health Administration

programmatic environmental impact statement

Project Management and Controls Support

Progress Tracking System

quality assurance

quality control

remedial action contractor

remedial action plans

sampling and analysis plans

suspected anomalies report

standard operating procedure

site observational work plan

Software Program for Environmental Analysis

Technical Assistance Contractor

TAC Action Item Logging System 


\section{LIST OF ACRONYMS (Concluded)}

$\begin{array}{ll}\text { Acronym } & \text { Definition } \\ \text { TAM } & \text { TAC action memo } \\ \text { TOM } & \text { total quality management } \\ \text { UMTRA } & \text { Uranium Mill Tailings Remedial Action } \\ \text { UPDCC } & \text { UMTRA Project Document Control Center } \\ \text { UPDCS } & \text { UMTRA Project Document Control System } \\ \text { USACE } & \text { U.S. Army Corps of Engineers } \\ \text { WSAP } & \text { water sampling and analysis plan }\end{array}$




\section{SITE CHARACTERIZATION (05)}

\section{RISK ASSESSMENTS (0501)}

\section{Baseline risk assessments (0501-01)}

The following activities are conducted at Uranium Mill Tailings Remedial Action (UMTRA)

Project sites for which formal baseline risk assessments (BLRA) are prepared:

- Preparing site-specific data collection objectives that include survey objectives and types of data to be collected (if any).

- Performing ecological field surveys and sampling to support the ecological portion of the BLRA.

- Performing water-use surveys and collecting other field and land-use information to support human health aspects of the BLRA.

- Evaluating exposure pathways and reviewing toxicological data for contaminants present at the site under study.

- Performing calculations, simulations, and other evaluations to assess risk for different age groups and different exposures as specified in the UMTRA Project BLRA methodology.

- Preparing for and participating in presentations of the BLRAs to agencies and the public, as appropriate.

- Preparing the draft BLRA document and presenting it to the DOE UMTRA Project for review.

- Preparing the final BLRA document and delivering it to the DOE UMTRA Project.

\section{Risk evaluations (0501-02)}

The following activities will be conducted at UMTRA sites that do not require a formal BLRA and at UMTRA sites with BLRAs that require follow-up risk evaluations. These requirements may be based on actions proposed by a state or local entity, such as rezoning or land development, or may be in response to public concerns about a site.

- Performing risk evaluations.

- Preparing and presenting risk evaluations to regulators and the public, as requested by the DOE UMTRA Project. 


\section{SITE OBSERVATIONAL WORK PLANS (0502)}

\section{Site observational work plans, Revision 0 (0502-01)}

Revision 0 of the site observational work plan (SOWP) is the initial document identifying additional characterization data needed to support the ground water program. Data needs such as water quality data, ecological data, and hydrologic data are discussed in sufficient detail to provide a suitable rationale for additional characterization activities. Revision 0 also delineates the suggested compliance strategy for meeting the ground water standards at the respective sites. Revision 0 may include preliminary modeling and other associated activities.

For sites where natural flushing is the compliance strategy, the SOWP effort includes institutional controls issues as part of the development of the compliance strategy.

The following types of activities could be associated with the SOWPS:

- Identifying and evaluating compliance strategy, institutional controls, biological/ ecological/cultural issues, engineering issues, and land-use issues.

- Performing risk assessments, hydrologic assessments, geochemical assessments, and modeling.

- Preparing for and attending public meetings.

\section{Site observational work plans, Revision 1 (0502-02)}

Revision 1 of the SOWP is developed around the field activities associated with Revision 0. Revision 1 builds on Revision 0 by further defining the compliance strategy and any other relevant arguments. This version of the SOWP also includes more detailed modeling activities.

For sites where natural flushing is the compliance strategy and a Revision 1 SOWP is required, this version contains a detailed analysis of institutional control issues associated with natural flushing.

Not all sites will have Revision 1 SOWPs. This would be the case where no additional information is needed to develop a ground water compliance strategy.

\section{Final site observational work plans (0502-03)}

The final SOWP sets the stage for the remainder of the ground water program for its respective site. Future documents such as environmental assessments (EA) and remedial action plans (RAP) will be based in part on the final SOWP. This version of the SOWP should contain all the necessary elements of a compliance strategy, as well as formal documentation of the data collection activities for the site. The final SOWP should contain the results of various types of modeling, if appropriate. 
For sites where natural flushing is the compliance strategy, this version of the SOWP will build on the previous analysis of institutional controls in support of natural flushing. For active remediation sites, the final SOWP could include preliminary design information for such things as waste water treatment plants.

\section{CHARACTERIZATION SYSTEMS INSTALLATION (0503)}

\section{Field plans/statements of work (0503-01)}

This effort encompasses all prerequisite activities in the work plan for performing fieldwork, as delineated in the SOWPs. These activities include the following:

- Developing detailed field plans/schedules/cost plans/statements of work supporting the SOWPs including data loggers and dedicated pumps.

- Identifying the need for appropriate clearances and permits.

- Preparing for and attending fieldwork scoping meetings.

- Conducting a DOE briefing to ensure participation and agreement on field plans and scope.

- Establishing real-world survey coordinates for key positions at each UMTRA processing site.

\section{Permitting (0503-02)}

This task identifies and plans for access, permitting, and regulatory compliance activities that must be accomplished prior to field site characterization activities. This activity may include the following tasks:

- Reviewing maps that show the proposed locations of activities and access, and reviewing information that describes the schedule, type, and nature of fieldwork. The purposes of these reviews are to

- Identify the prefield approvals required, the source of approvals (e.g.. land owner, regulatory agency), and the timing requirements to support proposed field schedules.

- Suggest locations for fieldwork if permitting or access problems are identified.

- Preparing permit applications.

- Drafting approval letters (e.g., cultural resource concurrences).

- Performing other activities to obtain necessary authorizations to conduct field site characterizations.

- Tracking the status of permits and approvals. 
- Advising site and technical managers of the status of compliance activities.

Land and water well access agreements are not included in this effort. Those efforts are under Work Breakdown Structure (WBS) 25, "Property Access and Acquisition Activities."

\section{Fieldwork/data loggers/dedicated pumps (0503-03)}

Activities include the following:

- Implementing the fieldwork needed to support detailed site characterization associated with the ground water contamination at former UMTRA processing sites.

- Conducting site visits to determine stilling well, weather station, and well point locations if appropriate, and determining if existing site-specific locations could be used.

- Installing low-flow pumps at selected wells at former UMTRA processing sites.

- Installing data loggers, dedicated pumps, and other equipment as required to support site characterization at applicable sites.

- Modeling (and associated activities) in support of data collection efforts. Hydrologic and geochemical evaluations and modeling efforts will be incorporated into the next version of the SOWP.

Deliverables under this WBS include meeting notes, field notes, and trip reports.

\section{Field test (0503-04)}

Field tests support active remediation activities. These activities may include initiating and conducting field tests at specific sites to verify the conceptual models and qualify the stress response to the systems that support the SOWP. Field tests include aquifer pumping tests, slug tests, and geophysical tests.

Deliverables under this WBS include meeting notes, field notes, and trip reports.

\section{Field procedure development (0503-05)}

This element includes preparing and developing procedures and safety rules and regulations in support of field activities. 


\section{DATA COLLECTION AND ANALYSIS (0504)}

\section{Data maintenance and validation (0504-01)}

Activities may include the following:

- Surveying sites when new data come to the Technical Assistance Contractor (TAC) from a subcontract laboratory using the suspected anomalies report (SAR) form, and evaluating the data.

- Reviewing site operational and monitoring history, and use as a possible explanation for some of the results or trends obtained.

- Maintaining the Software Program for Environmental Analysis (SPEAR) database for the site-specific data.

- Maintaining, updating, and optimizing the ground water database, ensuring that established data validation procedures for the UMTRA Ground Water Project are maintained.

- Providing data management support at the appropriate level to validate data.

\section{Water sampling and analysis plans (0504-02)}

Activities may include the following:

- Preparing water sampling and analysis plans (WSAP) to conduct routine ground water sampling and analysis in support of the Ground Water Project, following site-specific sampling and analysis plans (SAP).

- Preparing and updating, as-needed, WSAPs that provide technical guidance and justification for ground water monitoring activities.

- Participating in briefings and meetings, as required.

\section{Routine sampling and analysis plans/fieldwork/analysis and reporting (0504-03)}

Activities may include the following:

- Developing SAPs specific to the water sampling events, including location and analyte selection and specifying quality control $(\mathrm{QC})$ sample types and locations.

- Preparing work orders for subcontract laboratories. These work orders are sent to the Contracts Department and then to the subcontractor.

- Performing sample collection fieldwork and completing field forms. 
- Reviewing field forms and transferring field data to the Information Systems Planning and Support (ISPS) Department for entry into the UMTRA Project database.

- Preparing the site hydrologist, toxicologist, and/or geochemist summary that is included in the validated data package.

\section{Calibration (0504-04)}

Activities may include the following:

- Monitoring natural flushing sites to help verify the conceptual models developed in the SOWPs. This monitoring is the first part of a multiyear data collection effort at natural flushing sites, where a long data baseline is needed for modeling and other evaluation activities.

- Developing SAPs specific to sampling events, including location and analyte selection and specifying $\mathrm{OC}$ sample types and locations.

- Preparing work orders for subcontract laboratories. These work orders are sent to the Contracts Department and then to the subcontractor.

- Performing sample collection fieldwork and completing field forms.

- Reviewing field forms and transferring field data to the ISPS Department for entry into the UMTRA Project database.

- Preparing a site hydrologist, toxicologist, and/or geochemist summary that is included in validated data package.

\section{Other (ecological, cultural, endangered species, geophysical surveys) (0504-05)}

This category of data collection activities includes all types of collection activities except water sampling.

Activities may include the following:

- Environmental and technical field surveys, studies, and evaluations as required to support field site characterization, access, remedial action, and environmental documentation requirements.

Environmental studies may include cultural resource surveys and evaluations, wetland/floodplain delineations, and threatened and endangered species studies.

Technical field surveys may include supervision of professional land surveyors to establish site horizontal and vertical control, installation and sampling of monitor wells for contaminant plume delineation, field surveys for identification of area hydrogeology, and geophysical surveys to evaluate subsurface hydrogeologic conditions. 
REMEDIAL ACTION COMPLIANCE AND DESIGN DOCUMENTATION (10)

\section{DRAFT REMEDIAL ACTION PLANS (1001)}

\section{Compliance demonstration (draft remedial action plans) (1001-01)}

These RAPs primarily discuss the requirements of a ground water compliance strategy, including hydrologic, geochemical, and risk evaluations. All RAPs include a demonstration of compliance. RAPs for natural flushing sites include details of the required institutional controls. The RAPs must contain enough information so that the U.S. Nuclear Regulatory Commission (NRC) and the other concurring agencies can agree with the compliance strategy.

\section{Conceptual design (draft remedial action plans) (1001-02)}

Draft RAPs include conceptual design information needed to support the selected active remediation technique or approach. This could include information required for a waste water treatment plant design. Issues associated with the conceptual design include groundwater extraction/injection, water treatment, and waste disposal. Only RAPs associated with active remediation sites contain this WBS element.

FINAL REMEDIAL ACTION PLANS (1002)

\section{Compliance demonstration/certification remedial action plans (1002-01)}

The final RAP is the decision document that the NRC and the state or tribe concur on in selecting a compliance strategy approach. This document contains all the elements the NRC needs to approve the selected approach. For natural flushing sites, the final RAP presents detailed institutional control information. The acceptance of natural flushing as the compliance strategy is based in large part on the application of adequate institutional controls.

\section{Final design remedial action plans (1002-02)}

The final RAP contains enough detailed design information (such as specifications) to allow the NRC to evaluate the selected design. The bid package is based in large part on the detailed design information in the final RAP. Only RAPS associated with active remediation sites contain this WBS element.

\section{Final independent technical review remedial action plans (1002-03)}

For sites that will be remediated using active remediation, a final independent technical review (ITR) will be conducted by an outside third party entity. The purpose of this review is to ensure all appropriate design issues have been addressed. This peer review is conducted before the final RAP is completed. The RAP incorporates relevant results of the peer review. 


\section{BID PACKAGE PROCESS (1003)}

\section{Prepare bid package (1003-01)}

Activities involve preparing performance-based specifications for a contractor to design, install, and operate a remedial action system. The bid package typically contains extraction locations and rates, treatment technology to be used (but not specific hardware), and discharge criteria. The bid package also contains standard terms and conditions and bonding and insurance requirements.

\section{Solicitation/evaluation/award bid packages (1003-02)}

This element includes activities associated with the advertisement and selection of a contractor. The contracts staff charge to this number while placing and evaluating bids. Technical staff charge to this number while determining if a contractor's submittal is responsive to the bid. This may include independent analysis of the contractor's proposed system, visits to proposed vendors, and a review of actual performance of similar units the contractor installed at other locations. 
ENVIRONMENT, HEALTH, AND SAFETY PROGRAM (15)

\section{ENVIRONMENTAL OVERSIGHT (1501)}

\section{Environmental compliance evaluations (1501-01)}

Programmatic and site-specific environmental compliance activities not directly associated with site-specific environmental assessments include the following:

- Preparing documentation supporting the site-specific National Environmental Policy Act (NEPA) process that may not be specifically tied to an EA.

- Preparing the following types of environmental documentation as directed and as required to support site-specific environmental compliance:

- Federal Register notices.

- Environmental checklists.

- Cultural resource evaluations.

- Wetlands/floodplains assessments.

- Mitigation action plans.

- Threatened/endangered species reports.

- Biological assessments.

- Environmental audits.

This element also provides the U.S. Department of Energy (DOE) with direct environmental support for administering and coordinating environmental activities. This includes the following activities:

- Supporting responses to direction and queries from DOE Headquarters (DOE-HQ) and DOE Albuquerque Operations Office and the Environment, Health, and Safety (EH\&S) Committee.

- Performing programmatic appraisals.

- Preparing for and responding to outside environmental audits, surveillance, and assessments.

- Tracking, reviewing, and performing detailed applicability analyses for new, revised, and draft environmental regulations to evaluate applicability to and potential impact on the UMTRA Ground Water Project.

- Maintaining the EH\&S operating envelope system, which includes the preliminary requirements identification database and the standards/requirements identification database. 


\section{Environmental compliance reporting (1501-02)}

Activities may include the following:

- Compiling and issuing environmental reports required for compliance with DOE Orders and federal and state regulations. These reports include

- Annual site environmental reports.

- Environmental permit reports (National Pollutant Discharge Elimination System, National Emission Standards for Hazardous Air Pollutants).

- Waste management reports.

- Other environmental reports as directed by the DOE.

- Developing and maintaining programmatic environmental plans and guidance documents required by DOE Orders and environmental regulations. These documents include

- UMTRA EH\&S Plan.

- Environmental Protection Implementation Plan.

- Environmental Monitoring Plan.

- Ground Water Protection Management Program Plan.

HEALTH AND SAFETY OVERSIGHT (1502)

Administration of health and safety $(1502-01)$

This task includes support in administering the UMTRA program and TAC health and safety program. Activities may include the following:

- Reviewing health and safety reports and requirements.

- Implementing applicable health and safety requirements.

- Responding to queries concerning health and safety activities.

- Maintaining health and safety documents and records.

- Tracking status of compliance with programs.

- Preparing documents such as the following:

- Contractor EH\&S Plan.

- Contractor EH\&S standard operating procedures (SOP).

- Occurrence reporting and processing system (ORPS).

- Occupational Safety and Health Administration (OSHA) reports.

- Auditable SARs. 


\section{Health and safety audits (1502-02)}

Activities under this category include the following:

- Planing and conducting health and safety audits as necessary to verify compliance with applicable health and safety regulations, direction, and agreements. Audits may be conducted of field site characterization activities, remedial action activities, Project activities, and UMTRA Project plans and procedures.

- Preparing audit reports to document the conduct and results of audits.

- Preparing corrective action plans and performing corrective actions in response to audit findings.

- Reviewing corrective action plans and following up as necessary to ensure corrective actions were taken as needed for compliance.

- Logging and tracking audit information in the audit database.

\section{Health and safety training (1502-03)}

Activities under this category may include the following:

- Identifying and providing appropriate definitions of health and safety training requirements.

- Maintaining a training matrix that identifies specific training requirements based on tasks performed.

- Tracking the status of staff training, including notification of training requirements and fulfillment of training requirements, using tools such as the training database.

- Attending health and safety training sessions (e.g., OSHA, cardiopulmonary resuscitation/first aid, U.S. Department of Transportation, blood-borne pathogens).

- Identifying, planning, and coordinating health and safety training opportunities for UMTRA Project staff.

- Preparing and presenting training or procure training from commercial sources, as appropriate, to maximize benefit to the UMTRA Project. 
PROGRAMMATIC ENVIRONMENTAL IMPACT STATEMENT (1503)

\section{Draft programmatic environmental impact statement (1503-01)}

Activities may include the following:

- Planning, preparing, publishing, and distributing the draft programmatic environmental impact statement (PEIS) for public review and comment.

- Planning and conducting public hearings on the public draft PEIS.

- Responding to comments and revising the draft PEIS based on DOE direction.

- Editing and proofing the PEIS, preparing a camera-ready version and the documentation needed to transmit the PEIS to the Government Printing Office (GPO) for publication and distribution.

- Completing revisions to the notice of intent (NOI).

- Preparing the NOI for publication in the Federal Register.

- Planning, preparing for, and conducting public hearings on the draft PEIS as directed. This includes preparing support materials (e.g., handouts, posters, overhead visuals) and preparing meeting notes and comment summaries.

Final programmatic environmental impact statement (1503-02)

Activities may include the following:

- Preparing, publishing, and distributing the final PEIS.

- Providing support, as directed, in preparation of the record of decision on the final PEIS.

- Responding to public comments on the draft PEIS and preparing a revised final PEIS based on public comments.

- Conducting internal reviews of the final PEIS, submitting the document for DOE review and approval.

- Responding to DOE review comments on the final PEIS.

- Preparing a camera-ready copy and documentation needed to transmit the final PEIS to the GPO for publication and distribution.

- Preparing draft Federal Register notices regarding the availability of the final PEIS and the record of decision to support the final PEIS. 


\section{ENVIRONMENTAL ASSESSMENTS (1504)}

\section{Draft environmental assessment (1504-01)}

This task includes the following activities associated with preparing draft NEPA documentation to assess impacts associated with the preferred site-specific ground water compliance strategy.

- Preparing EAs and/or categorical exclusions.

- Assisting, when directed by the DOE, in conducting public meetings regarding sitespecific NEPA documentation. Funding for these activities resides at the site level.

Activities associated with site-specific EAs could include the following:

- Performing wetlands/floodplains assessments, biological assessments, threatened/endangered species evaluations, and cultural resource evaluations.

- Preparing environmental checklists, mitigation plans, and threatened/endangered species reports.

The Ground Water Project is assumed to require no environmental impact statements.

\section{Final environmental assessment (1504-02)}

This task includes the following activities associated with preparing the final NEPA documentation related to site-specific ground water compliance strategy implementation:

- Responding to comments on the draft documents developed under WBS 1504-01.

- Preparing, reviewing, and publishing a revised version that addresses review comments.

- Preparing a draft finding of no significant impact, as appropriate.

- Assisting in conducting (or participating in) public and/or agency meetings and consultations, as requested.

Other activities associated with site-specific EAs could include the following:

- Performing wetlands/floodplains assessments, biological assessments, threatened/endangered species evaluations, and cultural resource evaluations.

- Preparing environmental checklists, mitigation plans, and threatened/endangered species reports. 
TECHNOLOGY ASSESSMENT (20)

\section{TECHNICAL STUDIES (2001)}

\section{Sandia Environmental Decision Support System/Sandia National Laboratories (2001-01)}

This element supports Sandia National Laboratories in its development of software for visualization and ground water modeling. Visualization tools are developed to support straightforward, graphical communication of complex technical concepts. Computer software is used in evaluating site characterization, remediation, and closure decisions.

\section{Waste Education Research Consortium (2001-02)}

Activities under this category include the following:

- Supporting the University of New Mexico Waste Education Research Consortium for bioremediation studies at UMTRA disposal sites (e.g., Shiprock and Tuba City).

- Initiating and completing ground water special projects.

\section{University studies (2001-03)}

Activities under this category include the following:

- Supporting the University of Arizona in its studies of contaminant uptake in plants. This effort includes a generic plant-uptake study (Phase I) and a site-specific study for Tuba City (Phase II).

- Initiating and completing ground water special projects as requested by the UMTRA Project Office.

\section{TECHNOLOGY TRANSFER (2002)}

\section{Technology review (2002-01)}

Work under this element assists in identifying technology applications as directed by the DOE. It also assists the DOE in identifying appropriate technologies for characterizing and remediating ground water contamination at UMTRA Project sites. Activities associated with the identification of technology may include the following:

- Reviewing appropriate technical literature.

- Attending seminars and workshops.

- Communicating with researchers in fields related to the UMTRA Project. 


\section{Technology exchange (2002-02)}

Work under this element assists in technology exchange as directed by the DOE. Activities may include the following:

- Hosting guest speakers on topics of interest to UMTRA.

- Preparing and/or reviewing papers for presentation at selected workshops or seminars.

- Participating in organizing exchanges with specialists from other countries dealing with technical problems similar to those of the UMTRA Project.

FIELD TECHNOLOGY APPLICATIONS (2003)

\section{Field plans (2003-01)}

Work under this element assists in developing field application plans for implementing or testing new technologies as directed by the DOE. Plans should be integrated into sitespecific activities for the sites where field activities are planned. Plans should be adequately complete and plainly written for agency review.

\section{Permitting (2003-02)}

Work under this element assists the DOE in obtaining all permits required to implement various technologies. Permits may include standard environmental, well drilling, waste water disposal, special use, or experimental permits.

\section{Fieldwork (2003-03)}

Fieldwork includes overseeing and/or assisting in any field activities associated with the implementing or testing new technologies as directed by the DOE. Activities may be performed in cooperation with national laboratories, universities, or other research groups. Activities should be coordinated with routine planned activities to minimize cost.

\section{Operations and monitoring (2003-04)}

Work under this element includes conducting, overseeing, and monitoring the operations of new technologies as directed by the DOE. Operations may be performed in cooperation with national laboratories, universities, or other research groups. Operations should be coordinated with routine planned activities and operations to minimize cost. 
PROPERTY ACCESS AND ACQUISITION ACTIVITIES (25)

\section{ACQUISITION SUPPORT (2501)}

\section{Acquisition assistance (2501-01)}

This element includes TAC assistance and coordination efforts in acquiring real property and property interests such as easements. The support would be to the various project participants including the U.S. Army Corps of Engineers (USACE), the Bureau of Land Management (BLM), and the affected states and tribes. The specific support activities include the following:

- Identifying project real estate requirements, developing plans for acquiring these requirements, supporting and coordinating the acquisition, and reporting the status of ongoing activities.

- Coordinating with the DOE Office of Chief Counsel, private land owners, and corporations to prepare and secure remedial action agreements to conduct remedial action.

- Preparing and defending annual real estate budget requests and projections.

- Reviewing documented studies (e.g., windfall profit determinations) to justify the need for acquiring property not controlled by the DOE.

- Ensuring that documented studies and proposals to acquire real property and plans for its use are made with full consideration of economy, efficiency, programmatic need, and all applicable laws and regulations.

- Ensuring that all reports, correspondence, and information disseminated are consistent with DOE Order 4300.1C, Real Property Management.

- Reviewing practices relating to acquiring and managing real property for conformity with DOE Order 4300.1C.

- Implement authorized real property actions.

- Advising and counseling stakeholders on real estate issues.

- Reviewing real estate language in the various programmatic and site-specific documents.

- Reviewing the adequacy of documentation under the "Uniform Appraisal Standards for Federal Land Acquisitions," 1973; Interagency Land Acquisition Conference, 1973; and Public Law 91-646 Uniform Relocation Assistance and Real Property Acquisition

Policies Act of 1972. 
- Drafting or modifying statements of work in the task orders of the various memoranda of understanding (MOU), ensuring adherence to the procedures governing the issuance and acceptance of requests for real estate services set forth under the management and program guidelines of the respective MOUs.

- Identifying necessary, site-specific real estate work and drafting work orders that describe the work to be accomplished.

- Coordinating with the BLM for the administrative withdrawal and jurisdictional transfer of public land from the BLM to the DOE and ensuring permanent rights-of-entry leading to the disposal cells from state or county roads.

- Coordinating with the BLM, USACE, and private property owners to extinguish existing unpatented mining claims; acquiring patented mining claims; and obtaining waivers on grazing permits.

\section{Property acquisition (2501-02)}

This work includes the tasks related to coordinating with the various state and federal agencies during the acquisition process. It includes drafting letters on behalf of the DOE, coordinating meetings, setting up and participating in conference calls, reporting on status, and communicating with the DOE's Facilities and Property Management Division.

\section{Water rights acquisition (2501-03)}

This element includes researching property ownership and appropriated and unappropriated water rights. It also includes coordinating with state engineers' offices and the appropriate federal and tribal water rights entities.

\section{ACCESS AGREEMENTS (2502)}

\section{Monitor well access agreements (2502-01)}

This element includes the following:

- Obtaining monitor well agreements and ensuring access to properties on which monitor wells will be constructed and maintained for long-term sampling.

- Acquiring licenses and permits, including use agreements, rights-of-way, rights-of-entry for construction, and railroad crossing.

- Drafting correspondence to private property owners, state and federal agencies, and local authorities. 


\section{Land access (2502-02)}

This element includes work associated with obtaining BLM and tribal rights-of-way and acquiring perpetual easements with private property owners.

\section{Perform annual inspection of acquired properties (2502-03)}

This element includes an annual review of all acquisitions, use, inventory, or disposal actions for all properties and interests acquired by the DOE to ensure proper maintenance of all property records.

\section{INSTITUTIONAL CONTROLS (2503)}

\section{Programmatic support for institutional controls (2503-01)}

This element provides programmatic support to the DOE on institutional control issues. Site-specific institutional control issues are charged against the respective documents (SOWPS or RAPs).

\section{UMTRA Project plan for institutional controls (2503-02)}

Activities may include the following:

- Preparing a programmatic document addressing strategies associated with institutional controls at natural flushing sites. This may also include, at the DOE's request, institutional control issues related to other than natural flushing sites. (Note: The format and content of this document is not yet determined.)

- Coordinating and participating in meetings that may include state and tribal agencies to develop the document. 
SITE REMEDIAL ACTIONS (30)

\section{CONSTRUCTION (3001)}

\section{Construction (3001-00)}

This element includes constructing or overseeing construction of any permanent facilities associated with ground water remediation. The facilities may include but are not limited to extraction wells, injection wells, monitoring wells, treatment facilities, and their associated mechanical parts.

\section{SITE OPERATIONS AND RESTORATION (3002)}

\section{Monitoring (3002-01)}

This element includes monitoring site operations and making recommendations for restoration or modification of remedial action facilities.

\section{CONSTRUCTION MANAGEMENT (3003)}

\section{Construction management (3003-00)}

This element includes operating and/or managing construction at all permanent remediation facilities.

\section{REMEDIAL ACTION OVERSIGHT (3004)}

\section{Quality assurance audits (3004-01)}

This element involves assisting the DOE in quality assurance (OA) audits to ensure that remediation activities are conducted according to appropriate orders, SOPS, and health and safety requirements.

\section{Completion report (3004-02)}

This task involves preparing the appropriate level of documentation needed to demonstrate compliance with ground water cleanup standards at each of the UMTRA Project sites.

The type of documentation needed depends on the compliance strategy implemented at each of the sites. For example, completion reports are prepared for sites where active remedial actions are implemented to comply with ground water standards. The completion reports should summarize the site remediation activities and their effectiveness and document current water quality conditions. They also may justify the application of alternative concentration limits, when operational data indicate further remediation is not practical or economical. 


\section{REMEDIAL ACTION MONITORING (3005)}

\section{Verification (3005-01)}

As a follow-up to calibration monitoring, verification monitoring includes ground water monitoring during the early stages of remedial activities at natural flushing sites. This monitoring verifies that the natural flushing model and the time periods required under this compliance strategy are viable.

Activities included during verification monitoring are modeling efforts and other, associated activities that track the monitoring results.

\section{Routine (3005-02)}

Routine monitoring is conducted at sites where the performance of active remedial systems needs to be assessed. The specifications for this monitoring are delineated in the site-specific RAP.

\section{Data management support (3005-03)}

Activities under this category include the following:

- Supporting the DOE in validating, storing, and managing all collected monitoring data, including entering field data into the Project database; entering data from the subcontract laboratory into the Project database; reviewing the data through use of the SAR; and formally validating the data for conformance with analytical method, quality control limit, holding time, chain of custody, and other QA documentation requirements.

- Assisting the DOE in preparing a report confirming that U.S. Environmental Protection Agency standards have been attained through remedial actions at each site. This report documents that all standards have been met and that no more remediation is required.

\section{Confirmation report (3005-04)}

This category includes providing support to the DOE in its preparation of a report confirming that the hydrologic system associated with a natural flushing site is performing according to DOE model predictions. This report is based on results obtained during the verification monitoring period. Upon NRC approval of the report, the site is turned over to the Grand Junction Projects Office for the remainder of the natural flushing period. 
LONG TERM SURVEILLANCE AND LICENSING (35)

\section{LONG-TERM SURVEILLANCE ACTIVITIES (3501)}

\section{Modify long-term surveillance plan (3501-01)}

This task involves the following activities:

- Preparing, reviewing, and approving of appropriate documentation to support long-term surveillance activities necessary for site licensing in compliance for the UMTRA Ground Water Project.

- Modifying long-term surveillance plans (LTSP) developed under the Surface Project as necessary to reflect long-term surveillance requirements for the Ground Water Project. The level and extent of modifications depends on the ground water compliance strategy implemented at each of the sites as well as the site-specific disposal option employed in the Surface Project (e.g., stabilized on the site, off the site, in place).

- Developing separate LTSPs to support the site ground water compliance efforts, if necessary.

- Revising LTSPS to incorporate NRC comments, upon completion of NRC review.

\section{CERTIFICATION AND LICENSING (3502)}

Activities associated with this element include preparation of the final paperwork associated with completing the licensing process for the ground water program. This includes the certification letter that is sent to the NRC. 


\section{TECHNICAL AND MANAGEMENT SUPPORT (40)}

\section{RESOURCE PLANNING/PERFORMANCE MEASUREMENT (4010)}

\section{Performance measurement (4010-01)}

Activities include the following:

- Providing Project controls support to integrate cost, schedule, and technical efforts of all four TAC team members.

- Providing Project Management and Controls Support (PMCS) for the UMTRA Project. The PMCS organization is responsible for the operation and maintenance of and enhancements to a comprehensive, earned value-based system that includes

- Detailed site-specific and level-of-effort schedules.

- Activities.

- Logic ties (critical path methodology [CPM]).

- Budget estimates.

- Actuals and accruals.

- Earned value.

- Cost and schedule variances.

- Change control logs.

- Providing a monthly status report in accordance with contractual reporting requirements.

- Preparing schedule reports, including the UMTRA Project master schedule (monthly), site-specific detailed CPM schedules, and various levels of milestone/activity reports. Report formats include organizational breakdown structure (OBS) (by department), WBS, and site-level details. This activity includes site management, technical management, and cost scheduler efforts to report Project progress on cost, schedule, and baseline work packages.

- Supporting quarterly invoicing and monthly records maintenance for the states' shares and reimbursements. This is for billing the states for 10 percent of the remediation costs, reimbursements for 10 percent of the states' work, and 100 percent of the tribes' work. This element also applies to maintaining records and providing estimates of states' shares for incorporation in cooperative agreements.

- Supporting coordination of the change control process at the Project level. This support includes the following activities:

- Reviewing the contractors' requests/notifications for completeness.

- Resolving issues with contractors and Project staff. 
- Reviewing funding requirements/availability with the Project Office financial officer.

- Entering the cost data from the submitted requests/notification into the change control board (CCB) log database.

- Attending and supporting the CCB meeting.

- Resolving outstanding meeting issues with the Project personnel.

- Preparing meeting minutes.

- Analyzing remaining contingency and remaining budgeted cost for work scheduled (BCWS) to be baselined.

- Validating budgeted at completion changes from the contractors.

\section{Project level performance reports $(4010-02)$}

Activities include the following:

- Supporting the DOE Project Controls Group in operating an Integrated Project Management System (IPMS), ensuring that the system complies with applicable DOE Orders and meets the needs of the Project, and interfacing with other Project participants to ensure the proper operation of the IPMS.

- Providing the DOE Project with monthly cost performance reports by site, WBS, and major contractors at the Project level for internal management.

- Providing the DOE Project with timely and auditable cost, schedule, and technical baseline information for the monthly DOE-HO Progress Tracking System (PTS) report by activity data sheet, to include the following:

- Funds status analysis.

- Current year BCWS, budgeted cost for work performed, and actual cost for work performed updates.

- BCWS projections for the out-years.

- Variance analysis for current period and cumulative to date.

- Estimate at completion forecast.

- Providing the DOE UMTRA Project with a quarterly Project Manager's progress report at the Project level to forecast funds status, contractor performance relative to the baseline, significant problems and recovery plans, and variance analysis for the quarter. 
- Providing the DOE UMTRA Project with a monthly schedule status report of DOE-HOmonitored milestones by site, and maintain the Project master schedule to include reports by outside agencies.

\section{Resource Planning (4010-03)}

This element includes overall planning, scheduling, and analysis activities other than those associated with federal budget preparation or day-to-day deliverable execution. General resource planning is performed to facilitate future execution, establish priorities, and assign staff to specific tasks. Annual replanning is conducted each fiscal year in response to DOE guidance, to plan in detail the upcoming year's assigned tasks. "What if" type planning activities are conducted during the course of the year to estimate the effects of various alternatives to existing planning. Those that demonstrate a benefit to the Project are then implemented through the baseline change control process.

Examples of activities included in the scope of this element are listed below.

- General resource planning.

- Planning, allocating, and coordinating staff assignments (resource planning and coordination during the execution of specific deliverables is part of the scope of the individual deliverable).

- Discussing, developing, and communicating priorities of the various tasks assigned to the TAC.

- Supporting, coordinating, and attending periodic resource planning meetings.

- Developing, analyzing, and reporting overall summaries of resource requirements, trends, forecasts, etc.

- Developing and supporting procedures and systems for resource planning.

- Sequencing and scheduling individual assigned tasks in accordance with established responsibilities, schedules, and priorities (e.g., maintain individual day planners).

- Developing generic planning guidelines to facilitate planning and budgeting of specific future tasks.

- Annual replanning.

- Planning, coordinating, and tracking annual fiscal year replanning efforts.

- Reviewing and discussing DOE replanning guidance.

- Preparing, disseminating, and reviewing internal replanning guidance. 
- Identifying and implementing specific changes to existing plans in accordance with approved guidance.

- Developing, reviewing, and producing replanning deliverables.

- Preparing baseline change documentation; presenting the documentation to the DOE and implementing approved changes into the baseline.

- "What if" scenarios.

- Respond to individual requests to develop alternative plans for evaluation and decision making by the DOE or TAC that are not associated with federal budget preparation or revision.

- Reviewing and discussing potential replan instructions.

- Developing and analyzing potential replanning in contrast to existing plans.

- Preparing baseline change documentation; presenting the documentation to the DOE and implementing approved alternative plans into the baseline.

This element does not include travel, capital equipment, or other direct costs (ODC).

\section{Federal budget cycle (4010-04)}

Activities under this category include the following:

- Providing individual detailed cost estimates for the UMTRA Ground Water Project.

- Preparing revisions as appropriate to provide at least one edition of the project planning level, target level, and final budget case for the Ground Water Project.

- Providing a total estimated cost projection by WBS and by site. The federal budget submittal includes the following core sections:

- Cost plan.

- Budget authority.

- BCWS plan.

- Milestone plan.

- Prior year analysis.

- Full-time equivalent plan.

- Preparing and presenting an estimate of total costs for each fiscal year.

- Providing ground water budgets to the DOE UMTRA Project during an annual Project "bottoms-up" review. 
- Supporting other DOE UMTRA Project-sponsored reviews, including DOE-HO independent cost estimate (ICE) reviews, budget validation reviews, baseline validation audits, and major Project cost estimate (MPCE) reviews.

\section{Budget reviews (4010-05)}

Activities under this category include the following:

- Supporting budget reviews, including the preparation and participation in DOE UMTRA Project and DOE-HO reviews, audits, and validations. This will include the following:

- ICE reviews.

- MPCE audits.

- DOE UMTRA Project reviews.

- DOE-HO baseline validations.

\section{Nonsite communication (4010-06)}

Nonsite communication activities include preparation for and participation in the following:

- Departmental weekly staff meetings (nonsite related).

- Weekly TAC Action Item Logging System (TAILS) and assistant project manager (APM) meetings and twice weekly standup meetings.

- UMTRA Project non-site related assistant project manager meetings, site management meetings, and technical management meetings.

\section{Strategic planning/reviews (4010-07)}

These activities include the following:

- Assisting in strategic planning and reviews by participating in "brain-storming" sessions (e.g., redefinition of the UMTRA WBS), development of the OBS, and internal compliance checks on other Project controls-related events.

- Producing graphic material for technical and management documents and presentations prepared by the TAC or the DOE UMTRA Project, as requested.

- Participating in internal reviews including the monthly Project critical issues review, midyear and year-end reviews, formal DOE-HQ compliance audits, and the DOE UMTRA Project Management System compliance review.

- Continuing the process of self-assessment to ensure continued improvement at the management services department level.

- Preparing documentation, at least quarterly, illustrating areas evaluated, findings, resolutions, and planned and actual schedule accomplishments. 


\section{PERSONNEL ADMINISTRATION (4020)}

\section{Supervision (4020-01)}

This element includes the following supervisory functions:

- Employee performance reviews.

- Management by walking around.

- Employee mentoring.

- Disciplinary actions.

- Employee counseling.

\section{Professional development (4020-02)}

Professional development activities include participation in seminars, symposiums, and conferences not specifically related to performance of a particular task or assignment, but designed for employee professional development.

This element should be charged to a nonsite number.

\section{Applied training (4020-03)}

Applied training activities include participation in formal training courses, both internal and external, directly related to performance of a particular task or assignment. Examples of applied training include Open Plan software training, geochemical model courses, or PTS software user training.

This element should be charged to a nonsite number. It should include training time, travel, tuition, and training supplies and facilities.

\section{Human resources $(4020-04)$}

The human resources function includes writing position descriptions, reviewing resumes, interviewing, and participating in the selection process. This includes recruiting, interviews, and new-hire orientation. The Human Resources Department is required to develop equal employment opportunity plans, coordinate savings plans, and administer employee benefits and participation.

\section{Total quality management (4020-05)}

This element is for activities associated with the total quality management (TOM) program. These activities include the following:

- Attending Quality Council bi-weekly meetings.

- Participating on quality improvement teams.

- Preparing quality improvement suggestions. 
- Administering and participating in the UMTRA cost reduction/productivity improvement program.

- Preparing, presenting, and attending TOM training programs.

- Administering the TOM program.

\section{ADMINISTRATIVE SERVICES (4030)}

\section{Accounting (4030-01)}

Accounting activity consists of accumulating and maintaining financial data related to the prime contract with DOE. This activity includes all direct accounting functions such as accounts payable, accounts receivable, and payroll for all TAC teaming partners. This also includes the teaming partners' activities to accumulate cost data for invoicing to Jacobs Engineering Group Inc. (JEG) and JEG activities to accumulate all TAC costs for invoicing to the DOE.

\section{Contract administration (4030-02)}

Contract administration includes all contract-related activities, including administering the prime UMTRA contract and various subcontracts (including teaming partners), purchasing all supplies and equipment, and accountability for UMTRA government-furnished equipment and property.

\section{Facilities, reception, and security (4030-03)}

Activities include the following:

- Operating and maintaining an operations office in Albuquerque, New Mexico, for the purpose of performing the tasks specified in this and subsequent task agreements negotiated under the terms of the contract. All TAC personnel directly assigned to the UMTRA Project conduct their activities in or from the DOE UMTRA Project in Albuquerque.

- Acquiring and maintaining the office space, phones, furniture, equipment, supplies, and services needed to fulfill the terms and conditions of this task assignment and the contract.

- Coordinating office moves.

- Covering the reception and message centers (on the fourth and tenth floors of the present building).

- Coordinating efforts to ensure a safe work environment.

- Providing security support, including assigning and controlling security identification badges. 


\section{Reproduction and mail distribution (4030-04)}

The reproduction and mail distribution functions under this task include the following activities:

- Copying nonsite documents as required (site-specific documents should be accounted for under the appropriate site-specific task).

- Sorting and distributing mail for the fourth and fifth floors and the UMTRA Project Document Control Center (UPDCC).

- Preparing outgoing mail and Federal Express, United Parcel Service, or other special delivery mail.

- Maintaining and inventorying office supplies.

- Maintaining fourth and fifth floor copy equipment and supplies.

This ODC is unique and is used most by the Publications Services Department.

\section{Secretarial support (4030-05)}

Secretarial support includes all secretarial activities that are not site-specific, such as typing nonsite documents, fourth and fifth floor phone duty, filing and copying documentation, making travel arrangements, and updating calendars.

\section{DOE computer support (4030-06)}

This task includes activities required to support the DOE end-user, such as SOS/Help calls, personal computer and Maclntosh hardware (computers and peripherals) maintenance and service, troubleshooting activities, helping with end-user software, and direction and guidance with information systems technology. This also includes orienting end-users with software and the UMTRA local area network (LAN) environment.

\section{Local area network administration and technical assistance contractor user support} (4030-07)

Activities include the following:

- Setting up and maintaining UMTRA employee identifications, passwords, and space allocation.

- Maintaining space, paths, drives, and backups on the LAN.

- Troubleshooting SOS and Help Line calls and hardware and software problems.

- Operating, setting up, relocating, dismantling, and salvaging hardware and software. 


\section{Information systems administrative support (4030-08)}

Information systems administrative support activities include acquiring computer supplies (disks, pads, mouses, and other miscellaneous items), maintaining file copies of licenses, agreements, other "legal" duties; and maintaining files of user profiles (user requirements, computer audit reports, and inventories).

\section{Special information systems development and support (4030-09)}

This task includes internal development of software applications used throughout the UMTRA Project that are not specific to any one department or group. This includes shared programs such as 411 , Vast Office Integrated Database, Automated Travel Logging and Awareness System (ATLAS), TAILS, and TRAIN.

\section{Nonlabor programmatic support $(4030-10)$}

This element includes nonlabor programmatic activities for all sites that do not correspond to a specific existing WBS element and cannot be planned against a specific site. In general, the following nonlabor components are captured in this WBS:

- Capital equipment.

- Subcontracts.

- ODCs.

The ODCs outlined below generally fall under this WBS element, unless the ODC is sitespecific and/or supports a specific WBS element. For TAC teaming partners, ODCs charged to the UMTRA contract in support of their specific activities should be planned in this WBS.

Some of the performing groups responsible for managing the ODCs are listed below. A \#\# sign for the performing group indicates several performers probably use the WBS element.

\begin{tabular}{||l|c|}
\hline \multicolumn{1}{|c|}{ ODC description } & $\begin{array}{c}\text { Performance } \\
\text { group }\end{array}$ \\
\hline \hline DOE office lease costs & 45 \\
\hline Office and equipment rental & 45 \\
\hline Temporary personnel & $\# \#$ \\
\hline Dues and memberships & $\# \#$ \\
\hline Corporate computer charges & 14 \\
\hline Employee relations & $\# \#$ \\
\hline Noncapital equipment & $\# \#$ \\
\hline Relocation & $\# \#$ \\
\hline Telephone and communications & 45 \\
\hline
\end{tabular}




\begin{tabular}{||l|c||}
\hline Equipment and supplies maintenance & 34 \\
\hline Computer supplies and software & 32 \\
\hline Health and safety supplies & 45 \\
\hline Office copiers & 45 \\
\hline Government Services Administration vehicle expense & 32 \\
\hline Site access fees/maps/title searches & 21 \\
\hline Recruiting & 45 \\
\hline Freight, postage & 34 \\
\hline Medical exams & 45 \\
\hline Miscellaneous expenses & $\# \#$ \\
\hline Audit team costs & 14 \\
\hline Technical exchange & 41 \\
\hline Equipment repair & 34 \\
\hline
\end{tabular}

ODC purchases less than $\$ 2500$ are charged to this nonsite WBS element. If possible, for ODC purchases greater than $\$ 2500$, the ODC should be planned site-specific against the WBS for the particular activity. If a more specific WBS element cannot be identified, this WBS element should be used. This includes charges for office supplies (group 34) and field supplies (group 32).

When possible, subcontract efforts should be planned against the specific WBS element being supported. Subcontract efforts (such as Dolan, Mohaghan, and Info Storage) usually support site-specific and/or other activity-specific WBS elements. The following subcontracts should be charged to a site-specific or activity-specific WBS element:

- Data Terminal - computer support.

- Professional Writing and Creative Computer Services - word processing.

- WordCenter, Inc. - word processing.

- SW Video - video productions support.

- Miscellaneous (e.g., training).

Capital equipment purchases such as computers and LAN equipment are usually nonsite and programmatic in nature, as these purchases support all sites and all WBS elements.

Travel should be planned against the WBS the travel effort supports. 


\section{PROJECT DOCUMENTATION (4040)}

\section{Project plan (4040-01)}

This element includes coordinating, writing, publishing, and maintaining various project management documents required by DOE Order 4700.1 . Specifically included are the final and published versions of the IPMS Description Manual, the Project Plan, and the Project Management Plan. These documents are maintained in a current status by conducting annual reviews and recommending revisions necessitated by changes in Project conditions.

\section{Technical assistance contractor management plan (4040-02)}

This element includes coordinating, writing, publishing, and maintaining a TAC Management Plan to reflect current contractor activities. The TAC Management Plan contains sections on TAC organization, management, planning and control, Project administration, technical approaches (both surface and ground water), and quality.

\section{Site Management Plan (4040-03)}

This element includes coordinating, writing, publishing, and maintaining the TAC Site Management Plan.

\section{Quality Assurance Implementation Plan (4040-05)}

This element includes coordinating, writing, publishing, and maintaining a Quality Assurance Implementation Plan.

\section{Technical assistance contractor task plans (4040-06)}

Activities include the following:

- Coordinating and preparing the draft DOE task assignment.

- Coordinating and preparing the TAC task plans, including reviews, revisions, approvals, and submissions to the DOE.

- Periodically reviewing cost, scope, and deliverable commitment dates and updating the individual task plans, as required.

\section{UMTRA Project Document Control Center (4040-07)}

In accordance with applicable regulations, DOE Orders, and contracting officer representative (COR) guidance, the UPDCC supports the COR by administering and maintaining the UMTRA Project Document Control System (UPDCS), as follows:

- Capturing, classifying, storing, safeguarding, and retrieving all UMTRA-related correspondence, reference materials, drawings, maps, specifications, photographs, and reports. 
- Inventorying, scheduling, and retiring all UMTRA-related correspondence, reference materials, drawings, maps, specifications, photographs, and reports.

- Building and maintaining a reference library. This effort includes locating, ordering, cataloging, checking out and in, and monitoring the use of reference materials.

- Establishing and maintaining on-line records and reference library databases, adding new databases and converting old records.

- Coordinating with other records centers and government agencies in locating, sending, and receiving documents (e.g., the Office of Scientific and Technical Information).

- Maintaining both the UPDCS and the DOE UMTRA Project Records Management System manuals, training personnel, and assisting with audits of both systems.

- Studying and developing, if feasible, the use of optical disk technology for storing and retrieving UMTRA Project documents.

ODC charges under this element include books and periodicals.

\section{Standard operating procedures (4040-08)}

Activities included in this element are as follows:

- Developing, maintaining, and updating UMTRA SOPs.

- Creating, modifying, and updating internal desktop procedures and guides.

- Updating UMTRA system descriptions.

\section{Long-term surveillance plan (4040-09)}

This task involves activities associated with programmatic guidance for LTSPs. Activities include the following:

- Reviewing current LTSP guidance documentation for applicability to the Ground Water Project.

- Revising as appropriate to reflect Ground Water Project requirements.

- Annually reviewing and preparing revisions to the programmatic guidance documents to reflect DOE, NRC, and other applicable agency comments and guidance.

\section{Technical approach to ground water restoration (4040-10)}

This element includes preparing, modifying, and maintaining the technical approach for ground water restoration for the UMTRA Project. This document provides general technical guidance for the ground water restoration phase of the UMTRA Project. It also provides a technical overview of the implementation of the ground water program, 
including the regulatory basis and requirements for compliance, and it provides a framework for program activities needed to meet those requirements.

\section{Annual status report (4040-11)}

This element includes designing, writing, editing, coordinating, publishing, and distributing the UMTRA Project annual status report.

\section{Programmatic Project documents (4040-12)}

This element includes documents that are required through special agreements or memorandums among the DOE and state and federal agencies (e.g., the annual Colorado cultural resources summary report and the annual Colorado economic impact report) that cannot be charged to another site-specific or activity-specific WBS element.

\section{TECHNICAL SERVICES (4050)}

\section{Nonsite field preparation facility $(4050-01)$}

This element includes nonsite activities at the field preparation facility, including preparation for audits and reviews and general administrative duties such as cleanup and inventory.

\section{Laboratory audits (4050-02)}

Laboratory audits encompass activities in support of vendor laboratory audits/reviews; periodic reviews of subcontractor performance; and preaward source selection reviews, analyses, and recommendation documentation. This effort also includes ODCs not directly chargeable to site-specific WBS elements.

\section{Programmatic public affairs (4050-03)}

Generally, this WBS element includes activities that help the UMTRA Project Manager administer the UMTRA Public Affairs Program by providing professional communications support. This includes public affairs planning and counsel, community relations, public participation, media relations, employee information, and communications training.

Specific activities include the following:

- Writing, editing, coordinating, publishing and distributing the annual UMTRA Public Affairs Plan.

- Writing and coordinating communication plans for all special events, except opening/ closing ceremonies and public meetings associated with ground water documents (PEIS, EAs, BLRAs, and SOWPs). Efforts in support of these documents are charged to the appropriate site-specific WBS element for the documents.

- Providing public affairs advice and counsel to DOE UMTRA Project, TAC, and remedial action contractor (RAC) managers and staff. 
- Reviewing existing public affairs materials to ensure they are current and appropriate. and recommending changes, updates, and new products as appropriate.

- Designing, writing, revising, coordinating, publishing, and distributing fact sheets, news releases (except for public meetings and opening/closing ceremonies), video products, brochures, displays, site manager newsletters, and other products as appropriate.

- Preparing and providing communication training for staff in the DOE UMTRA Project, RAC, and TAC; and coaching individuals for special events as required.

- Researching, writing, and coordinating newsletter stories; editing and proofreading copy; taking photographs; designing, laying out, and writing headlines; publishing; and distributing the monthly UMTRA newsletter. This includes time spent researching and writing stories for "News Flash" on the UMTRA LAN.

- Maintaining and updating the UMTRA Project public affairs mailing list. This includes one complete review/update per year.

- Assisting DOE UMTRA Project management and staff in preparing for and accomplishing media interviews. This includes research, individual coaching, making interview arrangements, monitoring actual interviews, and evaluating interviewees afterwards.

- Taking media queries; researching, writing, and coordinating answers; responding to reporters; and recording the questions and answers in the public affairs database.

- Maintaining good relations with site communities. This includes answering public inquiries, providing speakers to public groups, showing the UMTRA display, and miscellaneous event support.

- Supporting Project relationships with local, state, tribal, and federal officials (e.g., assisting with written and oral communications, preparing briefings, arranging meetings).

- Providing planning and logistic support for public meetings (except those supporting ground water documents [PEIS, EAs, BLRAs, and SOWPs]), international workshops and visits, and special reviews/inspections. This includes the annual states and tribes meeting.

ODCs associated with the following activities are covered by this WBS element:

- States/tribes meetings.

- Groundbreaking ceremonies/closing ceremonies.

- Public relations/meetings/advertisements. 
- Groundbreaking and closing ceremonies and public meetings will be charged to the respective site.

If possible, Public Affairs ODCs should be charged to site-specific or activity-specific elements. When ODCs cannot be allocated specifically, this WBS element should be used.

\section{Programmatic quality assurance (4050-04)}

This programmatic OA WBS element includes all general QA activities not directly chargeable to site-specific accounts.

\section{Independent technical review (4050-05)}

This element includes all ITR activities such as corporate support, consultants, and expert reviews. This element account includes both labor and ODC (subcontract) charges but not ITRs conducted on final designs for active remediation sites (WBS 1002-03). This element also includes Roy F. Weston's ongoing revision of MK's invoices.

\section{Publications administration (4050-06)}

Publications administration includes activities required to administer and oversee the Pubtracker and Doctracker systems. It also includes routine administrative functions for the Publications Services Department, such as maintaining files, developing standards, preparing administrative forms, coordinating staff and assignments, evaluating and selecting hardware and software, establishing priorities, and acquiring temporary support.

\section{General technical management support (4050-07)}

General technical management support includes activities supporting the DOE that cannot be charged against site-specific or activity-specific WBS elements.

\section{Technical data and program administration (4050-08)}

The scope of work for this element includes a wide range of programmatic (nonsite) tasks related to procurement, management, storage, and retrieval of UMTRA Project technical data. Most charges under this number cover TAC staff-to-TAC staff consulting. DOE requests for technical support made to TAC staff or management should be charged to WBS element 405007 . Site-specific activities should be charged under the site budget; activities that are programmatic or preliminary and cannot be charged to a site can be charged under this WBS code.

Specific activities may include the following:

- Evaluating, programming, and upgrading the SPEAR database.

- Evaluating the need for and creation of additional technical databases. 
- Evaluating technical issues related to collecting field data and samples; $Q A$ and quality control issues related to those samples; and sample integrity and documentation.

- Supporting efforts related to data entry, including reviews of checking procedures, work related to electronic downloads from Project instrumentation (e.g., data loggers), and liaison with laboratories and other sources of data related to electronic deliverables.

- Evaluating statistical issues related to technical data.

- Providing technical support for acquiring and using geochemical, statistical, and hydrogeologic models.

- Providing technical support for acquiring and using hydrogeologic and geochemical field instrumentation.

- Supporting geographic information systems and related activities.

- Providing nonlaboratory-related analytical chemistry support for data acquisition efforts. Items more closely related to services performed by TAC subcontract laboratories should be charged to WBS element 405002 .

- Developing policies and systems for creating calculation sets and other archived documentation of assumptions, data, equations, and calculations underlying Project technical activities.

- Providing technical support to the UPDCC in areas related to data storage and retrieval.

\section{ACTION MEMOS (4060)}

\section{DOE action memos (less than $\$ 5000$ and 100 hours) (4060-01)}

This element includes DOE requests (less than $\$ 5000$ ), including all TAC action memo (TAM) support estimated at less than 100 hours.

\section{Individual action memos lover $\$ 5000$ and 100 hours) (4060-02 through 4060-99)}

This element includes DOE requests (estimated over \$5000), including all TAM support estimated at more than 100 hours. These TAMs are processed in accordance with the TAM procedure, using the baseline change request process to establish budget for the specified work. A unique charge number is established to capture the cost of each TAM greater than 100 hours. 


\section{LIST OF CONTRIBUTORS}

The following individuals were primarily responsible for the preparation of this report.

\begin{tabular}{ll}
\hline Name & Contribution \\
\hline D. Bierley & Document Coordinator \\
J. Torline, J. Jones & Technical editing \\
L. Sanchez & Word processing \\
\hline
\end{tabular}




\section{REFERENCES}

Interagency Land Acquisition Conference, 1973. Uniform Appraisal Standards for Federal Land Acquisition.

\section{DOE ORDERS}

4300.1C, Real Property Management, U.S. Department of Energy, UMTRA Project Office, Albuquerque Operations Office, Albuquerque, New Mexico.

4700.1, Project Management System, U.S. Department of Energy, UMTRA Project Office, Albuquerque Operations Office, Albuquerque, New Mexico.

\section{PUBLIC LAW}

91-646, Uniform Relocation Assistance and Real Property Acquisition Policies Act of 1972. 